\title{
THE MINERALOGY AND GEOCHEMISTRY OF ZEOLITE-BEARING VOLCANICS FROM AKROTIRI (SANTORINI ISLAND) AND POLYEGOS (MILOS GROUP OF ISLANDS), GREECE. IMPLICATIONS FOR GEOCHEMICAL CLASSIFICATION DIAGRAMS
}

\author{
K.P. KITSOPOULOS ${ }^{1}$, P.W. SCOTT ${ }^{2}$, C.A. JEFFREY ${ }^{1}$ AND N.G. MARSH ${ }^{4}$
}

\begin{abstract}
Almost 100 samples of volcanic rocks from Akrotiri (Santorini Island) and Polyegos (Milos group of Islands) were studied. Clinoptilolite and mordenite dominate the mineralogy in Akrotiri and Polyegos respectively. In Akrotiri, an acidic mainly precursor, probably a rhyodacite-dacite type of rock, was the parent precursor, although some samples indicate a more basic one. In Polyegos, it seems that a trachyandesite/rhyodacite type of rock has acted as precursor. However, this could be due to the possible depletion of $\mathrm{Y}$ under hydrothermal alteration, the increase of the $\mathrm{Nb} / \mathrm{Y}$ ratio, and the shift (in the $\left(\mathrm{Nb} / \mathrm{Y} \mathrm{vs}\right.$. $\mathrm{Zr} / \mathrm{TiO}_{2}$ diagram) of the nature of the precursor towards a more alkaline character. Thus, the true nature of the unaltered fresh precursor could actually be closer to the rhyodacite-dacite type of rock field. Geochemical classification diagrams using $\mathrm{SiO}_{2}$, $\mathrm{Na}_{2} \mathrm{O}$ and $\mathrm{K}_{2} \mathrm{O}$ are not suitable for use with such materials. Diagrams using less mobile elements, such as $\mathrm{Zr}$, Ti, $\mathrm{Nb}$ and $\mathrm{Y}$ are much more reliable, but with hydrothermal alteration conditions, their usefulness is variably restricted, and they should also be used with caution.
\end{abstract}

KEY WORDS: volcanic tuffs, ignimbrite, pyroclastics, parent rock, precursor, hydrothermal alteration, zeolite minerals, Santorini, Polyegos, Greece.

\section{INTRODUCTION}

Zeolite minerals, such as clinoptilolite and mordenite, are often found as alteration products in volcaniclastic materials. The zeolitization involves a diffusion-controlled hydration, mainly of volcanic glass, and an alkali ion exchange procedure. As a result, the zeolitization involves the relative gain and losses of elements initially present, especially alkaline and alkali earths and Si. Under these conditions, the geochemical nature of the parent materials is extremeley difficult to establish. The indiscriminate use of geochemical classification diagrams is not appropriate.

In this study, we examined the petrological characteristics of zeolite-bearing pyroclastics from Akrotiri (Santorini Island) and Polyegos Island (Greece). So far, because of their zeolitization, these materials have not attracted any considerable attention, especially on their geochemistry. Their mineralogy and geochemistry was investigated by using XRD and XRF respectively. The objective was to verify the nature of the parent pyroclastic materials (i.e the nature of the precursors for the formation of zeolites), using geochemical classification diagrams. The $\mathrm{SiO}_{2}$ vs. $\mathrm{K}_{2} \mathrm{O}$ (Rickwood, 1989) and the $\mathrm{SiO}_{2}$ vs. $\mathrm{Na}_{2} \mathrm{O}+\mathrm{K}_{2} \mathrm{O}$ (Le Maitre et al., 1989), as well as the $\mathrm{Nb} / \mathrm{Y}$ vs. $\mathrm{Zr} / \mathrm{TiO}_{2}$ (Winchester and Floyd, 1977) diagrams were finally used. The limitations which result from the application of these diagrams with zeolitized materials, are discussed.

\section{MATERIALS}

\subsection{Santorini Island}

The Islands of Thera (Santorini), Therasia and Aspronisi are the remnants of the Santorini stratocone, while Old and New Kameni are the products of a later volcanism (Figure 1). According to Pichler and Kussmaul (1972), a calk-alkaline, high-alumina, basalt-andesite-dacite type of volcanism erupted in Santorini from 8 centres. It began in Akrotiri, where the Lumaravi pyroclastics, mainly expressed as ash and/or lapilli tuffs and tuff breccia, were the initial volcanic products. The sequence also includes minor flows or breccias of hornblende

1. Geology Department, Leicester University, Leicester, LE1 7RH, UK. Correspondence to: Aiolou 16, P.Faliro, Athens, 175 61, GREECE.

2. Camborne School of Mines, University of Exeter, Redruth, Cornwall, TR15 3SE, UK. 
dacite, and some more basic rocks such as small domes/flows of andesites and basalts. This study used 47 samples from the entire tuffs outcrop.

\subsection{Polyegos Island}

Kanaris (1989) considered the Polyegos pyroclastics as a unit of fine-grained glass shards and pumice fragments tuffs, formed during a single eruption (Figure 1). Following the deposition of the tuffs, lavas were erupted, mainly of rhyolitic composition, forming lava domes and flows. Fyticas and Vougioukalakis (1992), divided the pyroclastics in two units; the "Prassa" ignimbrite (eruption between 2.0 and $1.7 \mathrm{Ma}$ ) and the "Myrsini" pyroclastics (eruption between 1.1 and $0.9 \mathrm{Ma}$ ). The lower part of Prassa ignimbrite includes submarine and terrestrial pyroclastic flows, with a very finely crystallised mass of glass shards and pumice fragments. The upper part is a fine grained, more massive, tuff consisting of pumice fragments and glass shards, with cross bedding structures, being created by surge mechanisms. The Myrsini pyroclastics consists mainly of pumice and some lapilli fragments of the Prassa unit; glass shards are absent. They can be characterised as lapilli tuffs which have undergone hydrothermal alteration. The type of alteration can be described as an intensive hydrolytic, acid sulfate, alteration, as evidenced from the presence of alunite-kaolinite/halloysite-quartz assemblages and Fe-rich bands in the area (Hemley and Jones, 1964; Kitsopoulos, 1995). Fifty three samples were collected, covering the entire outcrop of the Polyegos pyroclastics. Samples P1-P20, P32-P33 and P40-P53 were taken from the Prassa ignimbrite and samples P21-P31 and P34-P39 from the Myrsini pyroclastics.

\section{ANALYTICAL METHODS}

The mineralogy was examined by XRD. The clay mineralogy was determined using the $<2 \mu$ fractions of the samples. Thermal tests were applied to distinguish the heulandite type minerals. The geochemistry was investigated by XRF. Various international standards, as proposed by Govindaraju (1989), were run with the samples as control on the quality of the analyses. The major elements values were determined on fused glass beads and the trace elements values on pressed powder pellets.

\section{RESULTS AND DISCUSSION}

\subsection{Mineralogy}

In Akrotiri samples, heulandite type of minerals, smectite, occasionally illite/smectite, and mordenite are the dominant components. The thermal tests showed that the reduction of the 020 diffraction peak of the heulandite type minerals was in all cases $<50 \%$. No polymorphic phases nor any complete destruction of the 020 peak was recorded. Following the suggestions by Alietti (1972), Boles (1972) and Boles and Surdam (1979) the results of the the thermal tests indicate the presence of clinoptilolite. The presence of clinoptilolite in the tuffs is confirmed by using a large number of microprobe analyses (Kitsopoulos, 2001). Opal-CT, kaolinite, quartz, halite, feldspar, amphibole, Fe-Ti oxides complete the mineralogy. The genesis of the zeolites in the Akrotiri pyroclastics has been discussed by Tsolis-Katagas and Katagas (1989) and Kitsopoulos (1995, 1997).

The mineralogy of the Prassa ignimbrite samples is dominated by the presence of mordenite, and clinoptilolite, illite, and illite-smectite subordinate. Opal-CT, quartz, feldspar, biotite and some minor kaolinite and halite were also found. The samples from the Myrsini unit are principally composed of kaolinite, halloysite, alunite, and amorphous silica. The genesis of the zeolite minerals has been discussed by Kitsopoulos (1997). Detailed microprobe studies had shown that the Polyegos mordenite includes typical Na-Ca members and exceptionally rich K-rich members (Kitsopoulos, 1998).

\subsection{Geochemistry}

The XRF analyses were initially plotted on the $\mathrm{SiO}_{2}$ vs. $\mathrm{K}_{2} \mathrm{O}$ and the $\mathrm{SiO}_{2}$ vs. $\mathrm{Na}_{2} \mathrm{O}+\mathrm{K}_{2} \mathrm{O}$ diagrams (Figures 2 and 3). The problems involved with the mobilisation and the redistribution of the alkalis during zeolitization are obvious from all plots. Because the magmatism of the South Aegean Sea Volcanic Arc has a calc-alkaline affinity, the samples might be expected to plot (on a $\mathrm{SiO}_{2}$ vs. $\mathrm{K}_{2} \mathrm{O}$ diagram) in the area between the low and high-K line boundaries within one of the andesite-dacite-rhyolite rock fields. However, the actual spread of the Akrotiri and Polyegos (Prassa ignimbrite) samples is wider. Potassium has clearly been affected by re-distribution processes, exhibiting in some samples gains relatively to a presumed initial magmatic content. By taking into account the total amount of alkalis $\left(\mathrm{SiO}_{2}\right.$ vs. $\left.\mathrm{Na}_{2} \mathrm{O}+\mathrm{K}_{2} \mathrm{O}\right)$ the spread of the parent rock types is narrowed. The majority of the Akrotiri samples plot in the dacite field, but a few samples still plot in the andesite, 

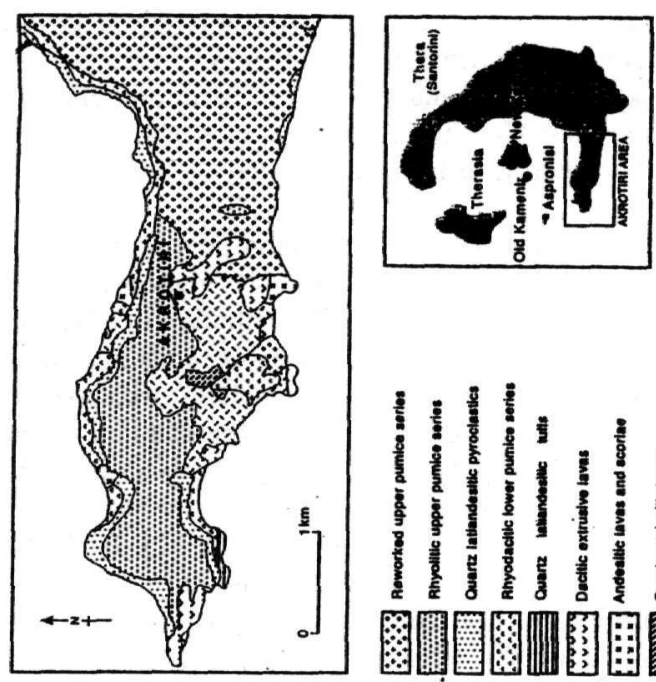

ఫ్ర

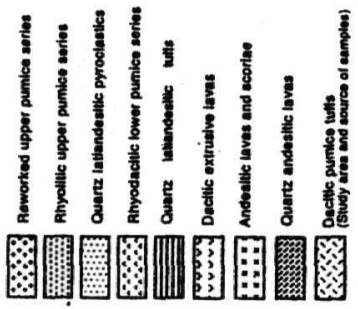

莡
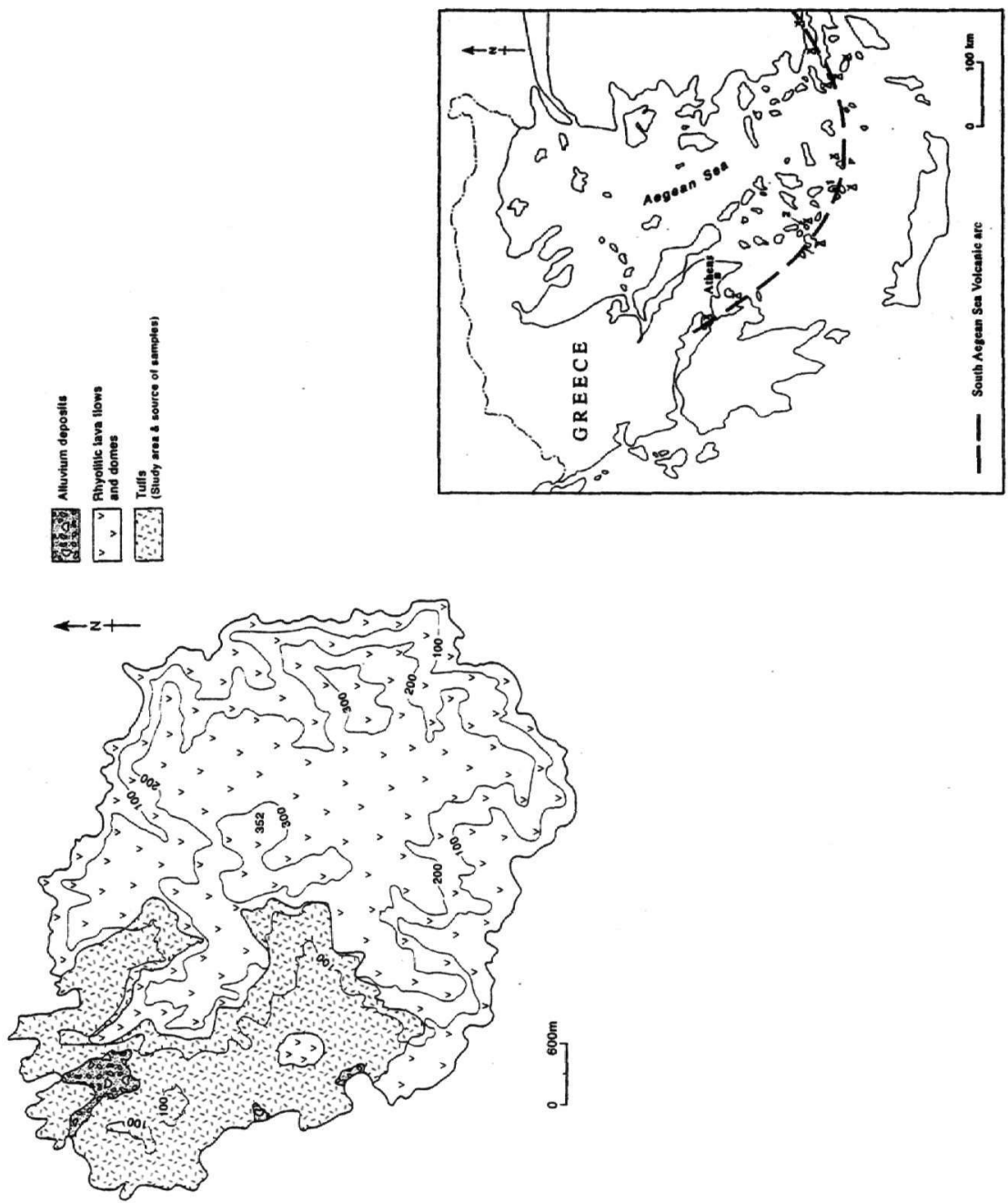
trachyandesite, trachydacite and rhyolite fields. The Polyegos (Prassa ignimbrite) samples plot in the dacite and rhyolite fields. The Myrsini samples which had suffered severe hydrothermal alteration show a wider spread, indicating as parent materials basalts to rhyolites type of rocks. It is highly unlikely that the eruption of single unit of pyroclastics would have given all these different type of rocks. Thus, the use of such type of geochemical classification diagrams with zeolitized or heavily altered rocks could lead to misinterpretation and incorrect conclusions.

An alternative approach to establish the nature of the parent materials is to use immobile trace element discrimination diagrams such as the $\mathrm{Nb} / \mathrm{Y}$ vs. $\mathrm{Zr} / \mathrm{TiO}_{2}$ diagram (Winchester and Floyd 1977) (Figures 2 and 3). In the diagram the $\mathrm{Zr} / \mathrm{TiO}_{2}$ ratio can primarily act as a differentiation index, as the differentiation of a basaltic magma can be traced by the decrease of $\mathrm{TiO}_{2}$, and to a less extent as an alkalinity index, as $\mathrm{Zr}$ tends to concentrate in alkaline rocks. The $\mathrm{Nb} / \mathrm{Y}$ ratio acts only as an alkalinity index (Pearce and Cann 1973) which corresponds with the higher concentrations of $\mathrm{Nb}$ in alkaline provinces. The field boundaries of the diagram should be viewed as marking gradational changes rather than sharply defined fields. The main purpose of using the diagram is not to characterise specific rock types, but to identify the nature of the parent material that acted as a precursor for the formation of these zeolite-rich rocks. According to Winchester and Floyd (1977), Ti, Zr, $\mathrm{Nb}$ and $\mathrm{Y}$ are immobile during post-consolidation alteration and metamorphic processes. The mobility of the trace elements is actually controlled by mineralogical changes during alteration and the nature of the fluid phase possibly involved. In this case it seems that first there was no mineral phase which actually controls the presence of $\mathrm{Ti}, \mathrm{Zr}, \mathrm{Nb}$ and $\mathrm{Y}$ elements and at the same time had taken part in the alteration procedure, and second the fluids did not exhibit any high $\mathrm{F}^{-}$activities. Using this trace element discrimination diagram almost all the Akrotiri samples plot in the field of dacite-rhyodacite and one in the andesite field. The majority of the Prassa ignimbrite samples plot in the fields of trachyandesite and few in the field of dacite-rhyodacite. Most of the Myrsini samples fall in the fields of trachyte, with only four samples plot as trachyandesites.

In Akrotiri, the formation of the zeolites should had been mainly facilitated by an acidic precursor, obviously a rhyodacite-dacite type of rock. However, it should be noted that some samples plot very close to the rhyodacitedacite/andesite boundary and one in the andesite field showing a more basic origin of their precursor. From the same diagram it can be suggested that there was no change in the alkaline affinity recorded during the eruption of the Akrotiri tuffs, but at the same time some degree of magma differentiation is recorded.

In Polyegos, the formation of the zeolites within the Prassa ignimbrite should had been originated from a rhyodacite-dacite/trachyandesite type of rock. From the same diagram it is obvious that during the formation of the Prassa ignimbrite there was no or very little magma differentiation recorded, but the alkalinity show some degree of differentiation. This change of alkalinity seems to be more prominent between the two units of the Prassa ignimbrite and the Myrsini pyroclastics. However, according to Finlow-Bates and Stumpfl (1981), although $\mathrm{Zr}$ and $\mathrm{Ti}$ can be considered as immobile elements under even intense hydrothermal alteration, Y and $\mathrm{Nb}$ can be removed from the altered products. The mineralogy of the Myrsini pyroclastics (principally alunite and kaolinite/halloysite) indicates that the rocks have been affected by severe hydrolytic alteration at extremely low $\mathrm{pH}$, possibly under high water:rock ratio. Under these conditions $\mathrm{Y}$ tends to be the least immobile elements of the four elements used. If we define $\mathrm{Y}$ as immobile under these conditions, then, the shift of the alkaline affinity recorded by the very high $\mathrm{Nb} / \mathrm{Y}$ ratios in Myrsini pyroclastics is valid, indicating the eruption of high alkaline products. But such alkaline rocks, in this area of the South Aegean Sea Volcanic Arc, could only be explained by a 'slab window' procedure taking place underneath the Arc. This is a process which could lead to the generation of such a high alkaline magma in such a subduction environment (Hole et al., 1991; 1994). Such a hypothesis, though, should be rejected as evidenced by the present day seismic activity, the numerous geothermal springs, and the signs of active volcanism (Santorini and Nisyros). Therefore, the high Nb/Y ratios of the samples from the Myrsini pyroclastics is probably due to $\mathrm{Y}$ depletion under the intense hydrothermal alteration the pyroclastics have suffered and is not inherited. Considering the fact that some hydrothermal alteration has affected the Prassa ignibrite too (Kitsopoulos, 1997), then, it can be suggested that the true nature of the parent precursor for the Prassa ignibrite could actually be closer to the rhyodacite-dacite type of rock field The Winchester and Floyd (1977) diagram must be used with caution for rocks which have suffered hydrothermal alteration. It also seems unreliable in hydrothermal environments where intense conditions and a high water:rock interaction ratio is suspected.

\section{REFERENCES}

ALIETTI, A. 1972. Polymorphism and crystal-chemistry of heulandites and clinoptilolites. Amer. Mineral. 57, 1448-1462. 

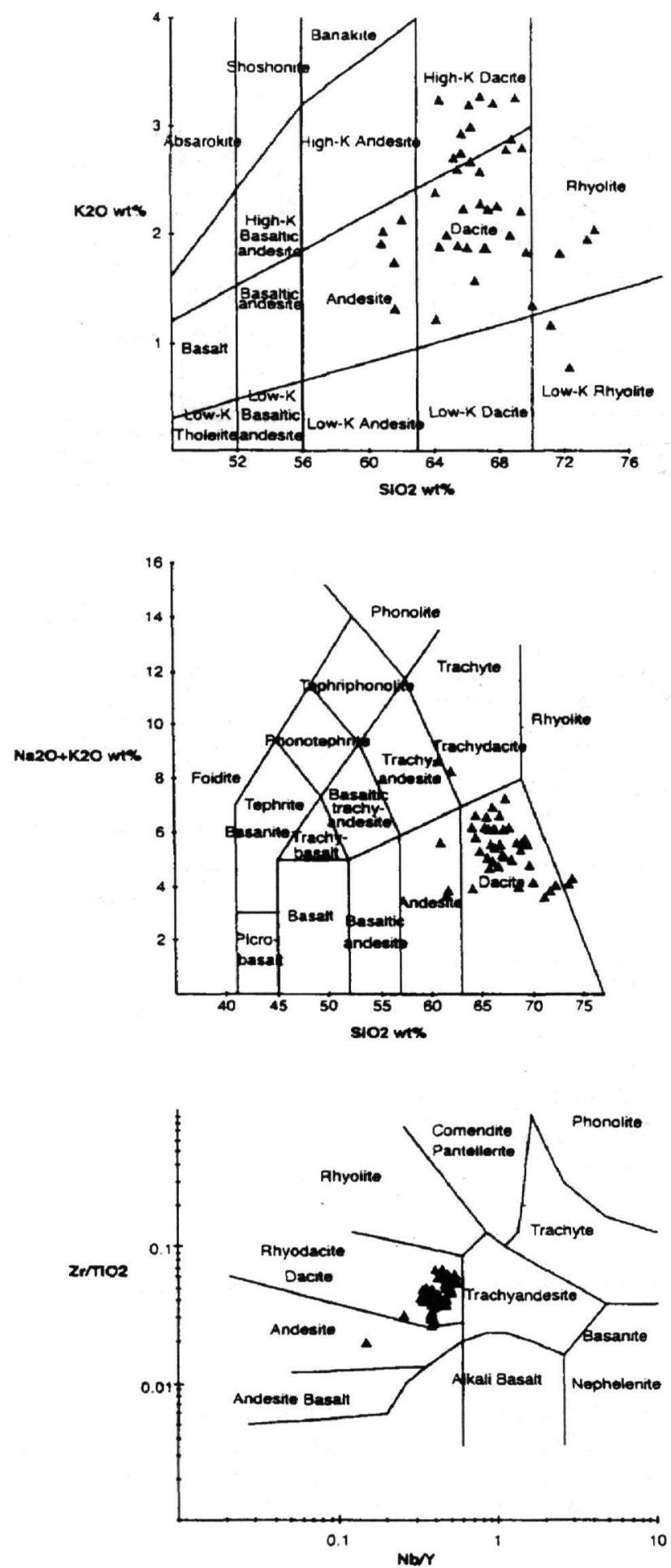

Figure 2. SiO2 vs. K2O (Rickwood, 1989), SiO2 vs. Na2O+K2O (Le Maitre et al., 1989) and Nb/Y vs. Zr/TiO2 (Winchester and Floyd, 1977) plots of XRF analyses of the Akrotiri zeolitized pyroclastics from Santorini Island,

Greece. 

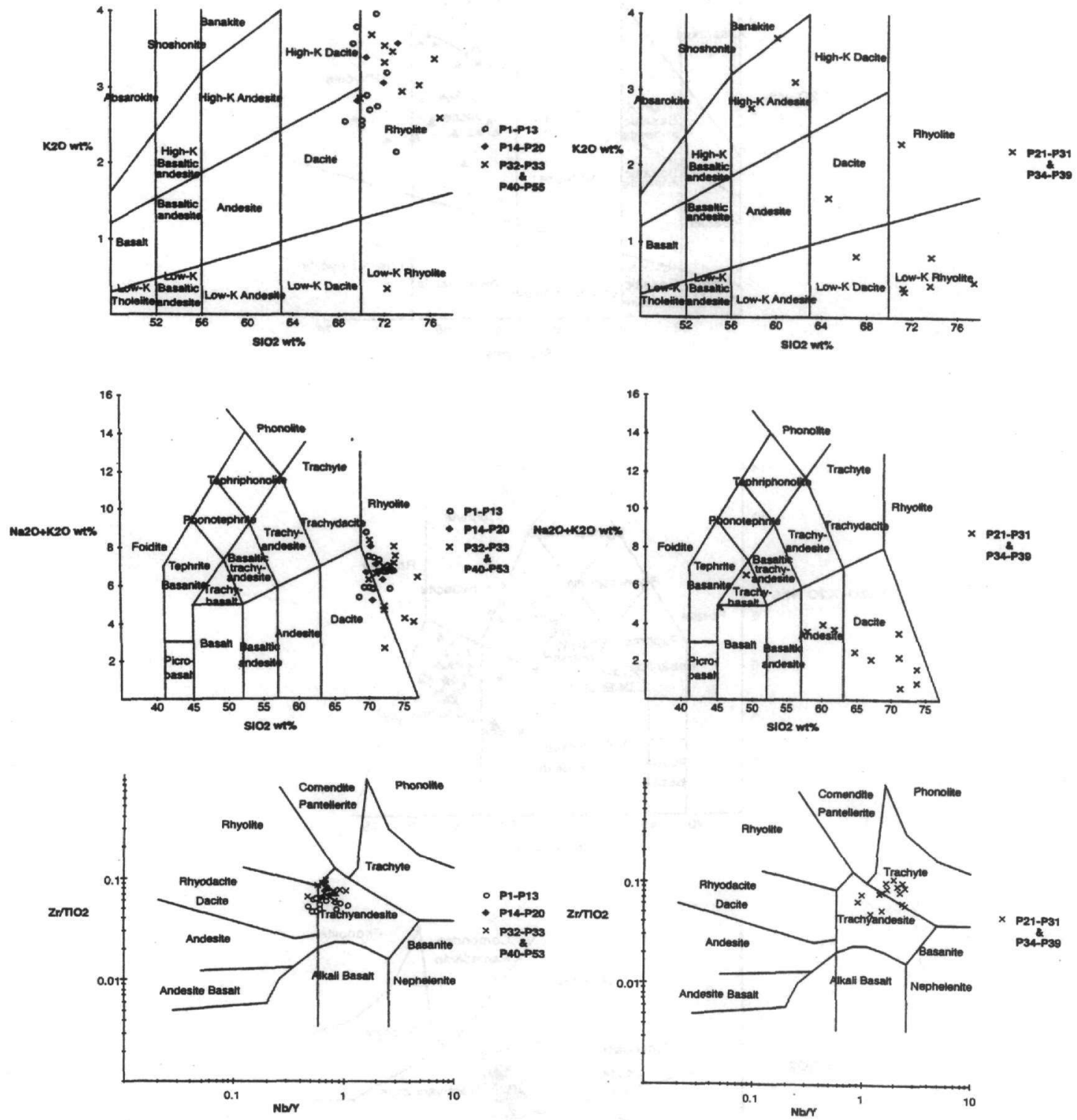

Figure 3. SiO2 vs. $\mathrm{K} 2 \mathrm{O}$ (Rickwood, 1989), $\mathrm{SiO} 2$ vs. $\mathrm{Na2O}+\mathrm{K} 2 \mathrm{O}$ (Le Maitre et al., 1989) and Nb/Y vs. Zr/TiO2 (Winchester and Floyd, 1977) plots of XRF analyses of zeolitized pyroclastics from Polyegos Island, Greece. Left column: samples P1-P13, P14-P20, P32-P33 \& P40-P53 (Prassa ignimbrite). Right column: samples P21-P31 \& P34-P39 (Myrsini pyroclastics). 
BOLES, J. R. 1972. Composition, optical properties, cell dimensions, and thermal stability of some Heulandite group zeolites. Amer. Mineral. 57, 1463-1493.

BOLES, J. R. \& SURDAM, R. C. 1979. Diagenesis of volcanogenic sediments in a Tertiary saline lake; Wagon Bed Formation, Wyoming. Am. J. Sci. 279, 832-853.

FINLOW-BATES, T. \& STUMPFL, E. F. 1981. The behaviour of so-called immobile elements in hydrothermally altered rocks associated with volcanogenic submarine-exhalative ore deposits. Mineral. Deposita 16, 319328.

FYTICAS, M. \& VOUGIOUKALAKIS, G. 1992. A report of the geological-volcanological-geothermal observations for Kimolos and Polyegos Islands. (Milos group of islands). Report by IGME (Institute of Geological and Mineralogical Research of Greece), Athens, 14 pp. (in Greek)

GOVINDARAJU, K. 1989. Geostandards Newsletters 13, Special Issue, July 1989.

HEMLEY, J. J. \& JONES, W. R. 1964. Chemical aspects of hydrothermal alteration with emphasis on hydrogen metasomatism. Econ. Geol. 59, 538-569.

HOLE, M. J., ROGERS, G., SAUNDERS, A. D. \& STOREY, M. 1991. Relation between alkalic volcanism and slab-window formation. Geology 19, 657-660.

HOLE, M. J., SAUNDERS, A. D., ROGERS, G. \& SYKES, M. A. 1994. The relationship between alkalic magmatism, lithosphere extension and slab-window formation along continental destructive plate margins. In: J.S. Smellie (Editor), Volcanism Associated with extension at Consuming Plate Boundaries. Geological Society of London, Special Publications 81, 265-285.

IGME. 1980. Geological Sheet "Thera". 1:50,000. Institute of Geological and Mineralogical Research of Greece, Athens.

KANARIS, I. T. 1989. Zeolites of the island of Polyegos. Report by IGME (Institute of Geological and Mineralogical Research of Greece), Athens, 21 pp. (in Greek)

KITSOPOULOS, K. P. 1995. The mineralogy, geochemistry, physical properties and possible industrial applications of volcanic zeolitic tuffs from Santorini and Polyegos islands, Greece. $\mathrm{PhD}$ Thesis, Leicester University, United Kingdom, 442 pp.

KITSOPOULOS, K. P. 1997. The genesis of a mordenite deposit by hydrothermal alteration of pyroclastics on Polyegos island, Greece. Clays and Clay Miner. 45, 632-648.

KITSOPOULOS, K. P. 1998. Compositional variations of mordenite from Polyegos island, Greece: Na-Ca and Krich mordenite. European Journal of Mineralogy 10, 569-577.

KITSOPOULOS, K. P. 2001. The relation between the thermal behavior of the clinoptilolite and its chemical composition. Clays and Clay Miner. 49, 236-243.

LE MAITRE, R. W., BATEMAN, P., DUDEK, A., KELLER J., LAMEYRE LE BAS, M. J., SABINE, P. A., SCHIMD, R., SORENSEN, H., STRCKEISEN, A., WOOLLEY, A. R. \& ZANETTIN, B. 1989. A classification of igneous rocks and glossary of terms. (Blackwell, Oxford).

PEARCE, J.A. \& CANN J.R. 1973. Tectonic settings of basic volcanic rocks determined using trace elements analyses. Earth Planett. Sci. Lett. 19, 290-300.

PICHLER, H. \& KUSSMAUL, S. 1972. The calc-alcaline volcanics rocks of the Santorini Group (Aegean Sea, Greece). Neues Jahrb. Mineral. Abh. 116, 268-307N.

RICKWOOD, P. C. 1989. Boundary lines within petrologic diagrams which use oxides of major and minor elements. Lithos 22, 247-263.

TSOLIS-KATAGAS, P. \& KATAGAS, C. 1989. Zeolites in pre-caldera pyroclastic rocks of the Santorini Volcano, Aegean Sea, Greece. Clays and Clay Miner. 37, 497-510.

WINCHESTER, J. A. \& FLOYD, P. A. 1977. Geochemical discrimination of different magma series and their differentiation products using immobile elements. Chem. Geol. 20, 325-343. 